\title{
CORROSION RESISTANCE OF PRESTRESSING STEEL WIRES
}

\author{
M. I. HREDIL, J. TORIBIO
}

\author{
University of Salamanca, E.P.S., Zamora, Spain
}

Cold drawing process is widely used for strengthening of wires made from pearlitic steels for reinforsed concrete structures. Then the steels undergo plastic deformation and the amount of defects rises. It could worsen their corrosion resistance. In this work the effect of cold drawing on the electrochemical behaviour of a pearlitic steel in alkali and neutral environments is investigated. Under passivation conditions in the environment with $\mathrm{pH} 12.5$ the changes in the steel properties are not fixed. The decrease in polarization resistance values and therefore corrosion acceleration as a result of the steel treatment is observed only in the vicinity of corrosion potential in $3 \% \mathrm{NaCl}$ solution.

Keywords: Prestressing steel, polarization curves, corrosion resistance.

Prestressing steel wires are widely used for reinforced concrete. Formation of a protective scale on a wire in an alkali concrete pore solution and its properties depend on many factors such as solution composition and $\mathrm{pH}$, temperature, surface state et al. The local depassivation of the prestressing wire made possible the start of the corrosion process in pits, which later can progress to the general corrosion. As a result the affective cross-section of wires decreases and cohesion between a wire and a concrete matrix weakens. The accumulation of corrosion products (iron oxides and hydroxides), occupying a volume several times larger than that of the original iron [1], leads to internal stresses that results in cracking and spalling of the concrete cover [2]. It has been shown [3] that the increase in volume of the rust product, associated with the reduction in diameter of reinforcement as small as $10 \ldots 50 \mu \mathrm{m}$, may result in cracks in the concrete.

Besides degradation in wires can occur due to long term service similar to other steels $[4,5]$ as a result of simultaneous action of working stresses and aggressive components of surrounding environment (pore solution in concrete). Chloride ions, for instance, may at appropriate potentials induce local breakdown of the passive film that would form in the $\mathrm{pH} 12.5$ environment and the $\mathrm{pH}$ within the pit may subsequently fall to low values because of hydrolysis [6]. The fractographic analysis of the fracture surfaces of the corroded prestressing wires showed that the brittle regions with a cleavage appearance can only be the result of the operation of hydrogen at the crack tip [7]. The occurrence of hydrogen is possible due to the presence of the free chlorides and the corrosion reaction, which provides the electrons needed for the transformation of $\mathrm{H}^{+}$ions into atomic hydrogen which then migrates into the metal crystal lattice.

Under the same environmental conditions corrosion resistance of metal itself becomes very important. Cold drawing process changes the initial material essentially and finally the material with different mechanical properties is obtained. It is important to know how does cold drawing process affect the corrosion activity and electrochemical properties of steel wires, and whether it is possible to reveal the anisotropy of this material by electrochemical testing. For this purpose the electrochemical behavior of pearlitic steel for prestressed concrete in two states, initial wire and after final stage of cold drawing process, was investigated.

Corresponding author: M. I. HREDIL, e-mail: mysya@usal.es 
Experimental method. The materials used were hot rolled bar (marked as E0) made of pearlite steel (mass.\%: $0.88 \mathrm{C}, 0.69 \mathrm{Mn}, 0.22 \mathrm{Si}, 0,010 \mathrm{P}, 0.024 \mathrm{~S}, 0.239 \mathrm{Cr}$, $0.076 \mathrm{Ni}, 0.010 \mathrm{Mo}, 0.129 \mathrm{Cu}, 0.118 \mathrm{~V}$, balance $\mathrm{Fe}$ ) and commercial $5 \mathrm{~mm}$ diameter prestressing steel wire (E7), obtained from E0 by 7-step cold drawing process. This procedure results in plastic deformation of pearlitic lamellas with their consistent rearrangement mainly in cold drawing direction creating highly anisotropic structure. Their mechanical properties are shown in Table 1.

Experiments were performed at room temperature $\left(20 \pm 1^{\circ} \mathrm{C}\right)$ in the solution containing $1 \mathrm{~g} / \mathrm{l} \mathrm{Ca}(\mathrm{OH})_{2}+0.1 \mathrm{~g} / \mathrm{l} \mathrm{NaCl}(\mathrm{pH} 12.5)$ with free oxygen access, which is sup-

Table 1. Dimensions and mechanical properties of steel $\mathbf{E}$

\begin{tabular}{|c|c|c|c|c|c|c|}
\hline \multirow{2}{*}{ Steel } & \multirow{2}{*}{$\begin{array}{c}D, \\
\mathrm{~mm}\end{array}$} & \multirow{2}{*}{$\varepsilon_{\text {plas }}$} & $E$ & $\sigma_{Y}$ & $\sigma_{R}$ & \\
\hline & & & \multicolumn{3}{|c|}{ GPa } & \\
\hline E0 & 11.3 & 0.00 & 199 & 0.72 & 1.23 & 0.068 \\
\hline E7 & 5.04 & 1.57 & 208 & 1.49 & 1.83 & 0.059 \\
\hline
\end{tabular}
posed to simulate a pore solution in concrete $[6,8]$. In some cases other solutions were involved. The standard electrochemical cell with saturated calomel reference electrode (SCE) and platinum wire as counter electrode was used for testing. Potentiodynamic polarization curves were obtained on the curved surfaces of cylindrical specimens (working surfaces were approx. $2 \mathrm{~cm}^{2}$ for both wires), their cut ends were insulated using varnish. The initial scale was removed by grinding with sandpaper to 600 grit. Then the specimens were degreased with ethanol, washed using distilled water and dried in air. The polarization curves were obtained by the potential scanning from stationary (corrosion) potential to the cathodic (or anodic) direction with a sweep rate of $1 \mathrm{mV} / \mathrm{s}$ and $0.5 \mathrm{mV} / \mathrm{s}$ for the linear polarization resistance (LPR) tests. Taking into account a possible scatter of results, at least 5 parallel tests were performed for each steel and solution, and three of them (more typical) are normally presented.

Results and discussion. The analysis of potential changes with time reveals passivation of the both steels in the tested environment (Fig. 1). Passivation dynamics is similar for steels E0 and E7. Tests were also performed on the end surface of the both materials (Fig. 1c, d) but in this case a big scatter of the results was fixed not only in steady-state value but also in dynamics of the process, so it is difficult to interpret the test results. The end surfaces passivate faster but curves are not uniform, obviously because other competitive processes are involved. This aspect requires further investigation. As the average values are considered it can be concluded that electrochemical potentials on the different surfaces (end and lateral) are not equal for each steel. Obviously the end surfaces are slightly more electrochemically heterogeneous and active (corrosion potential is lower). Afterwards we tested only the lateral surface since just it is in a contact with environment in real conditions.
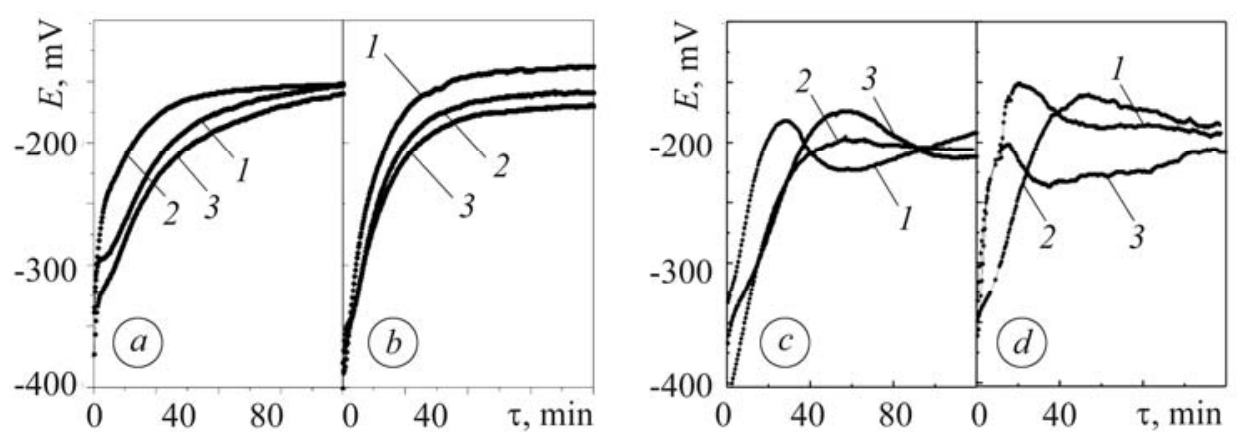

Fig. 1. Changes of electrochemical potential with time for the steels E0 $(a, c)$ and E7 $(b, d)$ measured at the lateral surface $(a, b)$ and at the cut end $(c, d)$ in the solution containing

$1 \mathrm{~g} / \mathrm{l} \mathrm{Ca}(\mathrm{OH})_{2}+0.1 \mathrm{~g} / 1 \mathrm{NaCl}(\mathrm{pH} 12.5)$. Numbers near the curves correspond to numbers of tests. 
Noticeable differences between steel E0 and E7 states in general were not observed in alkali environment, obviously because of passive scale formation which conceals the true properties of materials.

Cathodic polarization curves are similar for the both steels (Fig. 2). In these cases the area of diffusion limit for oxygen reduction can be observed. The following current increases under more negative potentials (starting from appr. $-1100 \mathrm{mV}$ ) caused by active hydrogen evolution. These data are in agreement with fundamental work of Parkins et al. [6], who tested a similar commercial presstressing steel in a wide range of potentials and solution compositions: noticeable effect of polarization on the mechanical properties was observed under cathodic potentials below $-900 \mathrm{mV}$ (SCE), and essential decrease in failure load under $-1100 \mathrm{mV}$.
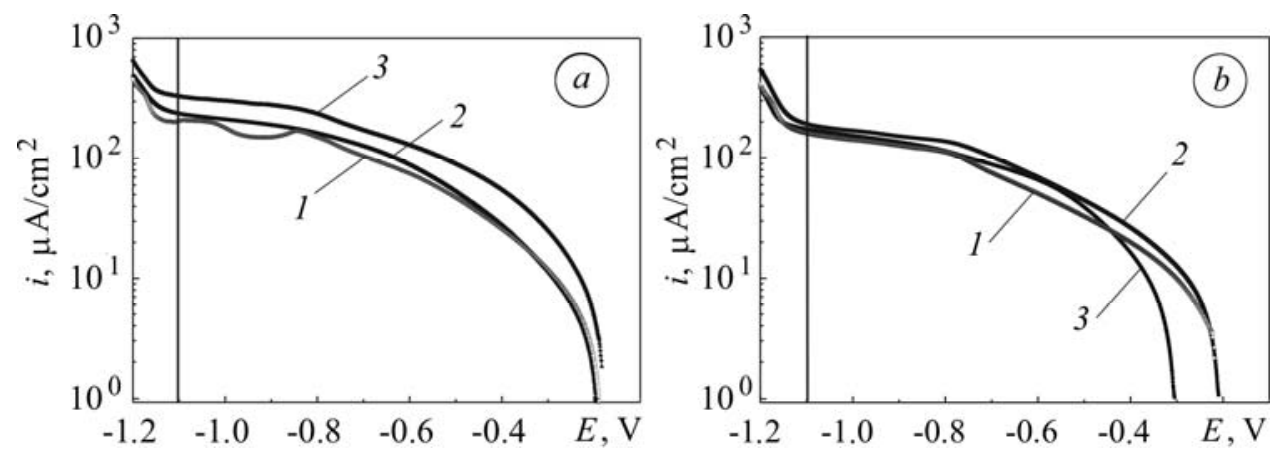

Fig. 2. Typical cathodic polarization curves for the steels E7 $(a)$ and E0 $(b)$ in the solution containing $1 \mathrm{~g} / \mathrm{l} \mathrm{Ca}(\mathrm{OH})_{2}+0.1 \mathrm{~g} / 1 \mathrm{NaCl}(\mathrm{pH} 12.5)$. Numbers near the curves correspond to numbers of tests.

It should be noted that a number of the slow strain rate tests were performed on smooth specimens made of the steel E7 under different cathodic potentials and displacement rates [9]. Effect of environment and hydrogen becames noticeable only under potential $-1100 \mathrm{mV}$ and lower (Table 2). Under higher crosshead speed fracture was observed inside and outside the cell. A result was unambiguous when crosshead speed was lower, fracture in the environment by the mechanism of hydrogen embrittlement, because in this case it was more time for hydrogen to affect the metal. Under more positive potentials specimens broke outside the cell.

Table 2. Qualitative results of SSRT for the steel E7 in alkali environment with pH 12.5 [9]

\begin{tabular}{|c|c|c|c|c|c|c|c|c|}
\hline \multicolumn{2}{|c|}{$E, \mathrm{mV}$} & -400 & -600 & -800 & -1000 & -1100 & -1200 & -1400 \\
\hline \multirow{2}{*}{$\varepsilon}$, & $10^{-6}$ & - & - & - & - & -+ & + & + \\
\cline { 2 - 9 } $\mathrm{s}^{-1}$ & $10^{-7}$ & - & - & - & - & + & + & + \\
\hline
\end{tabular}

- Fracture in air (outside the cell); + fracture in the solution.

Electrochemical behavior of steels E0 and E7 under anodic potentials in the alkali solution is similar (Fig. 3) revealing the passivity region between 200 and $650 \mathrm{mV}$ because of the formation of passivating layers on the steels surface. Obviously these layers don't possess good protective properties: they only suppress corrosion current but don't lead to complete passivation of steels which could be accompanied with drastic decrease of dissolution current.

After passive zone the dissolution intensifies dramatically. It can be caused by two reasons - appearance of pitting due to presence of $\mathrm{Cl}^{-}$ions in the solution or reaching of transpassive potential. Transpassive potentials are associated with a sharp increase in current due to dissolution of the passive film and oxygen evolution (i. e. water oxida- 
tion). In order to elucidate the possible contribution of $\mathrm{Cl}^{-}$ions into this process experiments were performed in the solution containing $1 \mathrm{~g} / \mathrm{l} \mathrm{Ca}(\mathrm{OH})_{2}$ without chlorides. The results are also shown in Fig. 3. It can be seen that the shape of anodic polarization curve and position of "breakdown" potential in particular does not depend on the presence of chlorides in the solution. Therefore the conclusion can be drawn that $\mathrm{NaCl}$ with concentration of $0.1 \mathrm{~g} / 1$ does not affect noticeably the process of anodic dissolution under used sweep rate within the tested range of potentials. Some effect of $\mathrm{Cl}^{-}$ions could be expected in this medium under lower sweep rate which provides deeper surface passivation. Similar results were obtained by Y. M. Tang et al. [10] who observed a rapid increase of anodic current near $0.66 \mathrm{~V}$ on the mild carbon steel in the simulated pore solution with $\mathrm{pH}$ 12.5. It may be due to the oxygen evolution reaction instead of the passive film breakdown, because after the test, no pits were observed on the surface of the steel specimen. Li and Sagüés [11] suggested that the actual $E_{\text {pit }}$ would be nobler than the oxygen evolution potential.

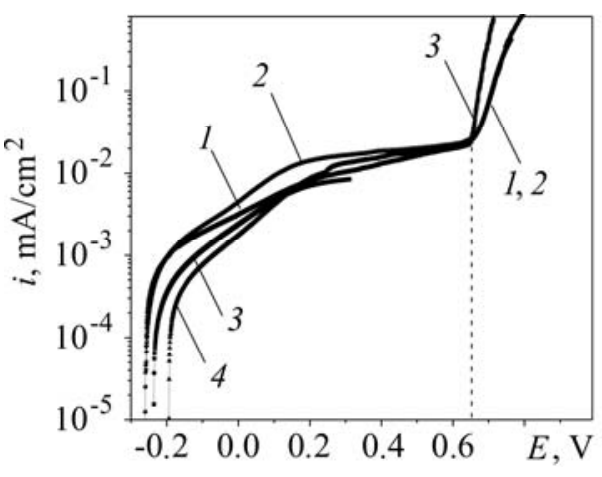

Fig. 3.

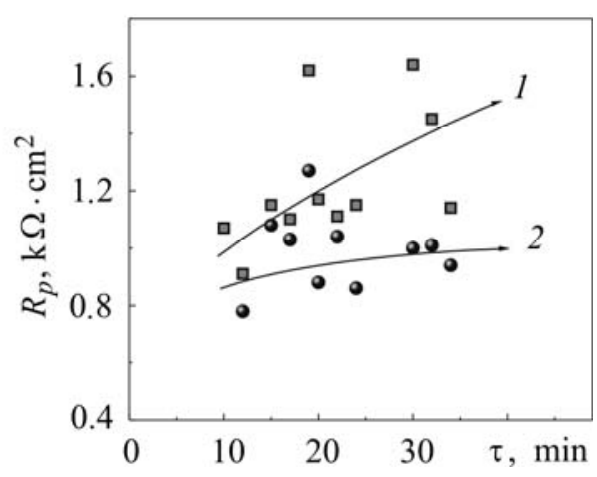

Fig. 4.

Fig. 3. Anodic polarization curves for steels $\mathrm{E} 0(1,2)$ and $\mathrm{E} 7(3,4)$ in $1 \mathrm{~g} / \mathrm{Ca}(\mathrm{OH})_{2}(1,3)$ and $1 \mathrm{~g} / \mathrm{l} \mathrm{Ca}(\mathrm{OH})_{2}+0.1 \mathrm{~g} / \mathrm{l} \mathrm{NaCl}(2,4)$.

Fig. 4. Time-depended values of polarization resistance for steels E0 (1) and E7 (2) in $3 \% \mathrm{NaCl}$ solution.

The $3 \% \mathrm{NaCl}$ water solution is well known and widely used as a high-aggressive neutral environment with depassivating properties. It allows us to avoid the effect of passive films typically formed in alkali environments.

In contrast to the alkali solution, the tendency of potential changes is inverse, potential shifts with time in the negative direction revealing active dissolution of the steels. The linear polarization resistance (LPR) method is chosen for evaluation of the corrosion activity of the tested steels. Among electrochemical test methods this one is supposed to be one of the most sensitive to materials state [12].

Polarization resistance values were determined mainly in the first half an hour after immersion of specimens into corrosive environment until its surface began to be covered by corrosion products. Number of the tests is sufficient for obtaining a clear tendency (Fig. 4). Under surface depassivation polarization resistance decreases approximately in 1.5 times for the commercial wire comparing to the initial state, revealing electrochemical activation caused by plastic deformation due to the cold drawing process.

\section{CONCLUSIONS}

Noticeable effect of significant plastic deformation due to cold drawing process on the corrosion resistance of eutectoid pearlite steel was observed only under low polarization in the vicinity of corrosion potential in the neutral environment. Decrease of polarization resistance at least in 1.5 times for a cold drawn wire indicates its 
electrochemical activation. Meanwhile, this effect does not reveal itself in the alkali media simulated service conditions for this steel therefore it couldn't influence the workability of this steel as a concrete reinforcement, and becomes apparent only in the case of substantional acidification of concrete pore solution.

РЕЗЮМЕ. Холодне волочіння широко застосовують для надання міцності пруткам перлітної сталі для залізобетонних виробів. При цьому сталь пластично деформується, зростає кількість дефектів, що може знизити ії корозійну тривкість. Досліджено вплив холодного волочіння на електрохімічну поведінку перлітної сталі у лужному та нейтральному середовищах. За умов пасивації поверхні в середовищі з $\mathrm{pH}$ 12,5 зміну властивостей сталі не зафіксовано. Зниження поляризаційного опору, а отже, корозійної тривкості сталі внаслідок обробки, спостерігали лише в околі потенціалу корозії у розчині $\mathrm{NaCl}$.

РЕЗЮМЕ. Холодное волочение широко используют для придания прочности пруткам из перлитной стали для железобетонных изделий. При этом сталь пластически деформируется, возростает количество дефектов, что может снизить ее корозионную стойкость. Исследовали влияние холодного волочения на электрохимическое поведение перлитной стали в щелочной та нейтральной средах. В условиях пассивации поверхности в среде с $\mathrm{pH} 12,5$ изменение свойств стали не обнаружено. Снижение поляризационного сопротивления, а значит, коррозионной стойкости стали в результате обработки, наблюдали только вблизи потенциала коррозии в растворе $\mathrm{NaCl}$.

1. Montemor M. F., Simões A. M. P., and Ferreira M. G. S. Chloride-induced corrosion on reinforcing steel: from the fundamentals to the monitoring techniques // Cement \& Concrete Composites. - 2003. - 25. - P. 491-502.

2. Греділь M. I. Експрес-методика оцінювання впливу корозії арматури на цілісність залізобетону. - Фіз.-хім. механіка матеріалів - 2013. - 49, № 3. - С. 102-104.

(Hredil' M. I. Express method for the evaluation of the effect of corrosion of reinforcement on the integrity of reinforced concrete // Materials Science. - 2013. - 49, № 3. - P. 394-397.)

3. Yüzer N., Aköz F., and Kabay N. Prediction of time to crack initiation in reinforced concrete exposed to chloride // Construction and Building Materials. - 2008. - 22. - P. 1100-1107.

4. Degradation of steels used in gas main pipelines during their 40 -year operation / H. M. Nykyforchyn, O. T. Tsyrul'nyk, D. Yu. Petryna et al. // Strength of Materials. - 2009. - № 5. - P. 501-505.

5. Студент О. 3., Свірська Л. М., Дзіоба І. Р. Вплив тривалої експлуатації сталі 12Х1МФ з різних зон гину парогону ТЕС на ії механічні характеристики // Фіз.-хім. механіка матеріалів. - 2012. - 48, № 2. - С. 111-118.

(Student O. Z., Svirs'ka L. M., Dzioba I. R. Influence of the long-term operation of $12 \mathrm{Kh} 1 \mathrm{M} 1 \mathrm{~F}$ steel from different zones of a bend of steam pipeline of a thermal power plant on its mechanical characteristics // Materials Science. - 2012. - 48, № 2. - P. 239-246.)

6. Environment sensitive cracking of pre-stressing steels / R. N. Parkins, M. Elices, V. SanchezGalvez, L. Caballero // Corrosion Science. - 1982. - 22, № 5. - P. 379-405.

7. Vehovar L., Kuhar V., and Vehovar A. Prestressing wires in a motorway viaduct // Engng Failure Analysis. - 1998. - № 1. - P. 21-27.

8. Toribio J. and Ovejero E. Hydrogen assisted cracking in progressively drawn pearlitic steel // Corrosion Science. - 2007. - 49. - P. 3539-3556.

9. Fernández-Viña A. Corrosión bajo tensión de armaduras activas para estructuras de hormigón pretensado / Proyecto fin de la carrera. - Universidad de Salamanca, 2009. - 187 p. (in Spanish)

10. Corrosion behavior of steel in simulated concrete pore solutions treated with calcium silicate hydrates / Y. M. Tang, Y. F. Miao, Y. Zuo et al. // Construction and Building Materials. - 2012. - 30. - P. 252-256.

11. Li L. and Sagüés A. A. Chloride corrosion threshold of reinforcing steel in alkaline solutions - cyclic polarization behavior // Corrosion. - 2002. - 58. - P. 305-316.

12. Греділь М., Звірко О. Застосування електрохімічних характеристик для оцінки деградації сталей тривало експлуатованих об'єктів // Фіз.-хім. механіка матеріалів. 2012. - Спецвип. № 9. - С. 51-55. 